\title{
Article \\ Effects of Nitrogen Conservation Measures on the Nitrogen Uptake by Cotton Plants and Nitrogen Residual in Soil Profile in Extremely Arid Areas of Xinjiang, China
}

\author{
Jinhu Zhi ${ }^{1,2,3}$, Taoyu Qiu ${ }^{2}$, Xinlu Bai ${ }^{1}$, Mengjie Xia ${ }^{1}$, Zhujun Chen ${ }^{1}$ and Jianbin Zhou ${ }^{1, *}$ \\ 1 College of Natural Resources and Environment, Northwest Agriculture and Forestry University, \\ Yangling, Xianyang 712100, China; zjhzky@163.com (J.Z.); bx10112@163.com (X.B.); xmj629@126.com (M.X.); \\ zjchen@nwsuaf.edu.cn (Z.C.) \\ 2 College of Agronomy, Tarim University, Alar 843300, China; taoyuqiu2022@163.com \\ 3 Research Centre of Oasis Agricultural Resources and Environment in Southern Xinjiang, Tarim University, \\ Alar 843300, China \\ * Correspondence: jbzhou@nwsuaf.edu.cn
}

Citation: Zhi, J.; Qiu, T.; Bai, X.; Xia, M.; Chen, Z.; Zhou, J. Effects of Nitrogen Conservation Measures on the Nitrogen Uptake by Cotton Plants and Nitrogen Residual in Soil Profile in Extremely Arid Areas of Xinjiang, China. Processes 2022, 10, 353. https://doi.org/10.3390/pr10020353 Academic Editor: Jingfeng Huang

Received: 19 January 2022 Accepted: 8 February 2022 Published: 11 February 2022

Publisher's Note: MDPI stays neutral with regard to jurisdictional claims in published maps and institutional affiliations.

Copyright: (C) 2022 by the authors. Licensee MDPI, Basel, Switzerland. This article is an open access article distributed under the terms and conditions of the Creative Commons Attribution (CC BY) license (https:// creativecommons.org/licenses/by/ $4.0 /)$.

\begin{abstract}
This study researched the effects of using various nitrogen $(\mathrm{N})$ conservation measures on the residual characteristics of nitrate and ammonium $\mathrm{N}$ in soil and the associated $\mathrm{N}$ uptake by cotton plants. A field experiment with six treatments was conducted, as follows, no N application (DT1), conventional $\mathrm{N}$ application (DT2), 60\% conventional N application combined with DCD (DT3), $60 \%$ conventional $\mathrm{N}$ application combined with NBPT (DT4), 60\% conventional $\mathrm{N}$ application combined with cotton straw returning (DT5), and 60\% conventional N application combined with DCD, NBPT, and cotton straw returning (DT6). The results showed that the cotton straws in the DT5 treatment were beneficial for the vegetative growth of cotton seedlings. However, it was observed that the later performance of the plants in this sample was poor in terms of height, biomass, and yield of cotton. The plant height in the DT6 sample increased by $15 \mathrm{~cm}$ compared with those in DT1, and the soil and plant analyzer development (SPAD) values of the fourth leaf from the top of the DT6 plants were higher than those in the DT1 and DT4 samples. The DT6 plants $(60 \%$ Urea + DCD + NBPT + cotton straw) increased $\mathrm{N}$ use efficiency by up to $47 \%$, and no significant decrease in biomass and cotton yield was observed compared to the DT2 sample. The residual content of nitrate $\mathrm{N}$ in the tillage layer increased gradually over time between two rounds of drip irrigation treatment applications. Compared with the DT2 treatment, the other treatments resulted in lower residual nitrate N contents. In summary, the application of $\mathrm{N}$ fertilizers at a reduced rate combined with $\mathrm{N}$ conservation measures may increase $\mathrm{N}$ use efficiency and decrease the risk of non-point source $\mathrm{N}$ fertilizer pollution, while maintaining the cotton yield.
\end{abstract}

Keywords: nitrogen reduction; nitrogen conservation; nitrogen uptake; NUE; cotton yield; extremely arid areas

\section{Introduction}

With its wide-ranging applications, cotton is the world's most vital economic crop [1]. The Tarim Basin in China is an arid region with a high cotton yield and unique climatic and soil conditions. It is located in China's main cotton planting region, Xinjiang, where cotton production accounts for $83 \%$ of the total national production [2-4]. Many factors affect cotton yield [5], among which nitrogen $(\mathrm{N})$ is the main limiting factor for its growth. Compared with other nutrients, the application of $\mathrm{N}$ fertilizer is necessary throughout the cotton growth period and cotton plants' demand for $\mathrm{N}$ is extremely high. Urea is the most common $\mathrm{N}$ fertilizer used for cotton production in China. Within two to three weeks after urea application, the fertilizer is converted to a mobile nitrate $\left(\mathrm{NO}_{3}{ }^{-} \mathrm{N}\right)$ through nitrification [6]. In addition, the volatilization of Nitrous oxide $\left(\mathrm{N}_{2} \mathrm{O}\right)$ due to denitrification 
and the volatilization of ammonia $\left(\mathrm{NH}_{3}\right)$ due to the presence of ammonium nitrogen $\left(\mathrm{NH}_{4}{ }^{+}\right)$results in the loss of most of the $\mathrm{N}$ fertilizer following its application to the soil. This massive release of $\mathrm{N}$ leads to serious problems in the water, air, and soil systems $[7,8]$.

To ensure environmental sustainability, it is necessary to reduce the damage caused by using $\mathrm{N}$ fertilizers while maintaining crop production and ensuring global food security. To make cotton development sustainable and to reduce the negative impact of $\mathrm{N}$ fertilization, the $\mathrm{N}$ utilization of plants needs to be made more efficient. An important improvement in this respect is the addition of $\mathrm{N}-(\mathrm{n}$-butyl) thiophosphoric triamide (NBPT) and dicyandiamide (DCD) to fertilizers [9], which are common urease and nitrification inhibitors, respectively.

DCD dissolves easily $\left(23 \mathrm{~g} \mathrm{~L}^{-1}, 13^{\circ} \mathrm{C}\right)$ and contains $65 \% \mathrm{~N}$ [10]. It inhibits the oxidation of $\mathrm{NH}_{4}{ }^{+}$to $\mathrm{NO}_{3}{ }^{-}$by inhibiting Nitrosomonas [10], which delays the nitrification of $\mathrm{NH}_{4}{ }^{+}-\mathrm{N}$ and improves the soil retention of $\mathrm{N}$, thereby increasing the utilization efficiency of $\mathrm{N}$ fertilizers and improving the $\mathrm{N}$ level in crops. The urease inhibitor NBPT $[9,11]$ inhibits $\mathrm{N}$ loss due to $\mathrm{NH}_{3}$ and $\mathrm{N}_{2} \mathrm{O}$ volatilization by reducing the hydrolysis rate of urea [12], and it exhibits an effective inhibitory effect on urea in a variety of soils when used at low dosages $[13,14]$. After NBPT is added to the soil, it is converted to oxon analog N-(nbutyl) phosphoric triamide (NBPTO) [15], which competes with Ni-enzymes for binding sites on the urea molecular structure, thereby inhibiting urea hydrolysis [16]. Existing studies on the joint use of wheat straws and urease inhibitors have shown that the presence of wheat straws, with or without the use of NBPT, prolongs the retention of $\mathrm{NH}_{4}{ }^{+}$in soils and reduces the formation of $\mathrm{NO}_{3}{ }^{-}[17,18]$.

For cotton $\mathrm{N}$ conservation, the reported performance of single biochemical inhibitors varies among studies, and few studies have reported on the effect on $\mathrm{N}$ conservation when a combination of inhibitors and straws is used, particularly in sandy loam soil within arid areas. Nitrification and urease inhibitors applied to dry land can significantly inhibit $\mathrm{N}_{2} \mathrm{O}$ emissions [19,20], reduce $\mathrm{N}$ leaching losses (by 38\% to 56\%) [21], and increase the $\mathrm{N}$ recovery rate of crops (by 34\% to 93\%) [22]. However, the performance of nitrification inhibitors is closely related to the type used, the soil and crop types, the application environment, and other factors [23]. Therefore, this study explores the differences in the $\mathrm{NO}_{3}{ }^{-}-\mathrm{N}$ and $\mathrm{NH}_{4}{ }^{+}-\mathrm{N}$ contents of tillage soil and in the growth status and yield of cotton plants under different $\mathrm{N}$ conservation measures in the extremely arid Tarim Basin in Xinjiang, China. Reducing the $\mathrm{N}$ dosage in fertilizers without reducing the cotton yield and the $\mathrm{N}$ utilization efficiency has important implications for the management of cotton fields and for decreasing non-point source $\mathrm{N}$ pollution in arid areas [24-26].

\section{Materials and Methods}

\subsection{Experimental Conditions}

A field test was conducted in Alar, Xinjiang Province. Alar is a city situated on the southern margin of the Tarim Basin $\left(40^{\circ} 22^{\prime}\right.$ to $40^{\circ} 57^{\prime} \mathrm{E}, 80^{\circ} 30^{\prime}$ to $\left.81^{\circ} 58^{\prime} \mathrm{N}\right)$. The test field was under the following conditions: annual mean temperature of about $10.7^{\circ} \mathrm{C}$, annual mean precipitation of 40.1-82.5 mm with an annual mean evaporation of $1876.6-2558.9 \mathrm{~mm}$. The test soil was sandy loam, and the physical and chemical properties of the $0-20 \mathrm{~cm}$ soil layer are shown in Table 1.

Table 1. Physical and chemical properties of the test field.

\begin{tabular}{|c|c|c|c|c|c|c|c|c|}
\hline $\begin{array}{l}\text { Water Content } \\
(\%)\end{array}$ & $\begin{array}{c}\text { Organic Matter } \\
\left(\mathrm{g} \mathrm{kg}^{-1}\right)\end{array}$ & $\underset{\left(\mathrm{mg} \mathrm{kg}^{-1}\right)}{\operatorname{Ammonium}} \mathrm{N}$ & $\begin{array}{c}\text { Nitrate } \\
\mathrm{N} \\
\left(\mathrm{mg} \mathrm{kg}^{-1}\right)\end{array}$ & $\begin{array}{l}\text { Available } \\
\text { Phosphorus } \\
\left(\mathrm{mg} \mathrm{kg}^{-1)}\right.\end{array}$ & $\begin{array}{c}\text { Available } \\
\text { Potassium } \\
\left(\mathrm{mg} \mathrm{kg}^{-1}\right)\end{array}$ & $\begin{array}{l}\text { Total Salt } \\
\left(\mathrm{g} \mathrm{kg}^{-1}\right)\end{array}$ & $\mathrm{pH}$ & $\begin{array}{c}\text { Electrical } \\
\text { Conductivity } \\
\mathrm{Mm} \mathrm{cm}^{-1}\end{array}$ \\
\hline 15 & 13 & 0.97 & 2.83 & 11 & 96 & 2.8 & 7.62 & 229 \\
\hline
\end{tabular}

\subsection{Experiment Design}

The cotton (Gossypium spp.) variety, Shikang 278, was grown in triplicate in six treatment types (DT1, DT2, DT3, DT4, DT5, and DT6) between 2019 and 2020. DT1 was a 
blank control (without $\mathrm{N}$ application), DT2 was a conventional control (with a $\mathrm{N}$ application rate of $450 \mathrm{~kg} \mathrm{ha}^{-1}$ ), and the $\mathrm{N}$ application rate of the other treatments was $60 \%$ of that in DT2 (i.e., an application rate of $270 \mathrm{~kg} \mathrm{ha}^{-1}$ ). The test design s shown in Tables 2 and 3 . The test was conducted using a completely randomized block design with three replicates each year. Each test plot area was 36 square meters and each treatment had three repetitions. Mulched drip irrigation was applied to the cotton. The planting densities of each treatment type test area were similar.

Table 2. Amount of base fertilizer applied.

\begin{tabular}{|c|c|c|c|c|c|c|}
\hline Types of Fertilizer & DT1 * & DT2 ** & DT3 & DT4 & DT5 & DT6 \\
\hline $\mathrm{N}\left(\mathrm{kg} \mathrm{ha}^{-1}\right)$ & 0 & 225 & 135 & 135 & 135 & 135 \\
\hline $\mathrm{DCD}\left(\mathrm{kg} \mathrm{ha}^{-1}\right)$ & - & - & 13.5 & - & - & 13.5 \\
\hline NBPT (kg ha $\left.{ }^{-1}\right)$ & - & - & - & 1.35 & - & 1.35 \\
\hline Cotton straw $\left(\mathrm{kg} \mathrm{ha}^{-1}\right)$ & - & - & - & - & 4500 & 4500 \\
\hline
\end{tabular}

* DT1 was the control treatment. ** The base fertilizer rate of DT2 was the same as that of conventional fertilizer $\left(225 \mathrm{~kg} \mathrm{ha}^{-1}\right)$.

Table 3. Amount of dressing fertilizer applied each time.

\begin{tabular}{|c|c|c|c|}
\hline Treatment & $N\left(k_{g ~ h a}{ }^{-1}\right)$ & $D C D *\left(k g h a^{-1}\right)$ & $\mathrm{NBPT}^{* *}\left(\mathrm{~kg} \mathrm{ha}^{-1}\right)$ \\
\hline DT1 & 0 & & \\
\hline DT2 & 28.125 & & \\
\hline DT3 & 16.875 & 1.70 & \\
\hline DT4 & 16.875 & & \\
\hline DT5 & 16.875 & & 0.17 \\
\hline DT6 & 16.875 & 1.70 & 0.17 \\
\hline
\end{tabular}

DCD was used as a nitrification inhibitor in DT3 and DT6 and was added at a rate of $10 \%$ of the $\mathrm{N}$ application rate. NBPT was applied as a urease inhibitor in DT4 and DT6 at a rate of $1 \%$ of the $\mathrm{N}$ amount. The $\mathrm{N}$ fertilizer used in each treatment was urea (N 46\%). Cotton straw was used as a fertilizer in DT5 and DT6. After the cotton straws were crushed, they were evenly mixed within the soil at an application rate of $4500 \mathrm{~kg} \mathrm{ha}^{-1}$ to a depth of 30-cm depth, prior to sowing. Double superphosphate was applied as a basal phosphate fertilizer at a rate of $138 \mathrm{~kg} \mathrm{ha}^{-1}\left(\right.$ as $\left.\mathrm{P}_{2} \mathrm{O}_{5}\right)$, potassium sulphate was applied as a basal potassium fertilizer at a rate of $78 \mathrm{~kg} \mathrm{ha}^{-1}\left(\right.$ as $\left.\mathrm{K}_{2} \mathrm{O}\right)$, and potassium dihydrogen phosphate (as 0-52-34) was applied as a phosphorus and potassium top-dressing at a rate of $450 \mathrm{~kg} \mathrm{ha}^{-1}$. The fertilizer dosage was $50 \%$ before sowing and $50 \%$ during the growth period.

Air and soil temperatures were measured two weeks after fertilization to characterize the test site conditions, as detailed in Table 4. The top-dressing was applied through drip irrigation for eight-day periods, and eight rounds in total were applied at an irrigation volume of $25 \mathrm{~m}^{3} \mathrm{ha}^{-1}$ per round.

Table 4. Fertilizer application date and associated air and soil temperatures.

\begin{tabular}{ccccc}
\hline Application Date & Air $\mathbf{T}_{\max }\left({ }^{\circ} \mathbf{C}\right)$ & $\operatorname{Air}_{\text {min }}\left({ }^{\circ} \mathbf{C}\right)$ & Soil $\mathbf{T}_{\max }\left({ }^{\circ} \mathbf{C}\right)$ & Soil $_{\text {min }}\left({ }^{\circ} \mathbf{C}\right)$ \\
\hline $\begin{array}{c}\text { 30 May 2019 } \\
\text { (base fertilizer) } \\
\text { 7 July 2019 }\end{array}$ & 31.0 & 20.0 & 32.2 & 26.3 \\
$\begin{array}{c}\text { (dressing fertilizer } \\
\text { 25 May 2020 }\end{array}$ & 32.1 & 21.3 & 31.5 & 25.5 \\
$\begin{array}{c}\text { (base fertilizer) } \\
\text { 28 June 2020 }\end{array}$ & 32.0 & 21.2 & 31.1 & 25.1 \\
(dressing fertilizer $\left.^{*}\right)$ & 33.1 & 22.5 & 32.2 & 26.2 \\
\hline
\end{tabular}

* Dressing fertilizer applied for an 8-day period. 


\subsection{Index Measurement Methods}

(1) Cotton plant height and number of true leaves on the main stem.

To conduct the measurements, three rows were selected in each plot, and 10 consecutive plants were selected in each row, totaling 30 plants per plot. The plant height was measured with a steel measuring tape from the cotyledonary node to the uppermost point of the plant. The number of true leaves on the main stem was defined as the number of leaves growing above the first two cotyledons, and this number was recorded for each of the five growth stages.

(2) Number and weight of bolls and the SPAD values of the fourth leaf from the top of the plant.

The number of bolls for each plant was determined by counting the number of mature bolls of 30 plants in a given plot (excluding young bolls, which measured less than $2 \mathrm{~cm}$ in length, and flower buds) and then averaging the number for the 30 plants. The seed cotton weight per boll in a given plot was determined by collecting the seed cotton from 30 pre-selected cotton plants on a regular basis after the bolls had opened, obtaining the total weight of the collected seed cotton, and dividing the total weight first by 30 and then by the number of bolls per plant. The SPAD value of the fourth leaf from the top of the cotton plant in each plot was measured during sunny, windless weather. Specifically, the SPAD values at three points on the fourth leaf from the top of the plant on the main stem of a pre-selected cotton plant were measured using a hand-held SPAD-502 chlorophyll meter (Konica Minolta Optics, Japan) and then averaged.

(3) Total N content of the cotton plants.

Ten cotton plants with uniform growth and development were selected from each test plot. The roots, stems, leaves, buds, and bolls were separated, thoroughly rinsed with tap water, rinsed 2-3 times with distilled water, placed on gauze on a table for 20 min to ensure they were fully dried, and then weighed. The treated specimens were then further dried at $105{ }^{\circ} \mathrm{C}$ for $30 \mathrm{~min}$ and baked at $80{ }^{\circ} \mathrm{C}$ until a persistent biomass weight was obtained. Specimens were crushed and the total $\mathrm{N}$ content was determined using the sulphuric acid-hydrogen peroxide digestion method.

The above measurements were conducted sequentially during the seedling stage (in June), the full budding stage (in early July), the full flowering stage (in late July), the boll-forming stage (in the middle of August), and the boll-opening stage (in late September).

(4) $\mathrm{NO}_{3}{ }^{-}-\mathrm{N}$ and $\mathrm{NH}_{4}{ }^{+}-\mathrm{N}$ contents of tillage soil.

The $\mathrm{NO}_{3}{ }^{-}-\mathrm{N}$ and $\mathrm{NH}_{4}{ }^{+}-\mathrm{N}$ contents of the $0-20 \mathrm{~cm}$ soil layer were monitored from the seedling stage to the budding stage (from 21 June to 4 July, starting from the second day of topdressing, samples were taken once a day for two consecutive weeks and marked as sampling days $1,2, \ldots, 15)$ and from the flowering stage to the boll-forming stage (from 14 July to 24 August, samples were taken once a week and marked as sampling days $24,32, \ldots, 64)$ following fertilization. This process was designed to reveal the nutrient content dynamics under the different fertilization treatments, with the ultimate aim of providing a theoretical basis for the optimum application of $\mathrm{N}$ fertilizer to cotton fields. The methods applied to measure the $\mathrm{NO}_{3}{ }^{-}-\mathrm{N}$ and $\mathrm{NH}_{4}{ }^{+}-\mathrm{N}$ contents can be found in previous studies $[27,28]$. In brief, fresh soil samples were leached using $1 \mathrm{M} \mathrm{KCl}$, and the leachate was analyzed using a flow analyzer (AutoAnalyzer 3 (AA3), SEAL Analytical $\mathrm{GmbH}$, Germany).

(5) The cotton yields were calculated according to Formula (1):

$$
\begin{aligned}
& \text { Seed cotton yield }\left(\mathrm{kg} \cdot \mathrm{hm}^{-2}\right)= \\
& \frac{\text { cotton number } \cdot \mathrm{hm}^{-2} \times \text { boll number for each plant } \times \text { weight of seed cotton for each boll }(\mathrm{g})}{1000}
\end{aligned}
$$

and the total $\mathrm{N}$ uptake by the cotton was calculated according to Formula (2):

$$
\mathrm{TN}=\sum \mathrm{wi} \times \mathrm{Ci}
$$


where TN refers to the total $\mathrm{N}$ uptake by the cotton, wi is the biomass weight of each part $(\mathrm{kg}), \mathrm{Ci}$ is the measured $\mathrm{N}$ content of each part $(\mathrm{g} / \mathrm{kg})$, and i represents the parts analyzed (roots, stems, leaves, buds, or bolls).

Furthermore, $\mathrm{N}$ use efficiency was calculated according to Formula (3):

$\mathrm{N}$ use effiency $(\mathrm{NUE}, \%)=\frac{\mathrm{N} \text { uptake }_{\mathrm{N} \text { fertilizer treatment }}-\mathrm{N} \text { uptake }_{\text {no fertilizer treatment }}}{\text { quantity of } \mathrm{N} \text { application }} \times 100 \%$

\subsection{Data Processing Method}

Plotting was performed using Origin 9.0 software, statistics (means and standard deviations) were calculated using SPSS 20.0 software, and a multivariate comparison was conducted using Duncan's test.

Statistical analysis was conducted using the restricted maximum likelihood estimation of variance components method. The covariance parameter for block $\times \mathrm{N}$ treatment $\times$ year was utilized to test the effects of the $\mathrm{N}$ fertilizer treatment and the interactions between $\mathrm{N}$ treatments and years. The year was assumed to be a random effect. A conventional LSD $(a=0.05)$ post hoc analysis was used to detect the statistical differences between the means. There were no significant interaction effects between treatment and year for any of the parameters analyzed in this study. Therefore, the results section only provides information about the main treatment effect of our investigations and the data are pooled across years.

\section{Results and Analysis}

\subsection{Cotton Growth Dynamics}

(1) Cotton plant height.

As shown in Figure 1, plant height is an important physiological index of cotton, and a suitable plant height is a prerequisite for a high cotton yield. After cotton topping, the cotton plant height increased gradually and tended to be stable. During the bollopening stage, the cotton plant height for the different treatments decreased in the order of DT6 $>$ DT4 $>$ DT5 $>$ DT3 $>$ DT2 $>$ DT1. During the seeding stage, there were no significant variations in the heights of the cotton plants between DT6, DT3, and DT4, but their heights were all greater than those of the plants in DT2 and DT1. The difference in the height of the cotton plants between DT6 and DT4 was not significant after the budding stage, but the cotton plant height for these two treatments was significantly greater than that for the other treatments. This result indicates that the application of urea with a nitrification inhibitor alone (DT3) and the application of urea with cotton straws alone (DT5) were unfavorable for increasing the height of cotton plants. Compared with DT6, DT3 contained a smaller amount of soil residual $\mathrm{NO}_{3}{ }^{-}$.

(2) Number of true leaves on the cotton plant main stem

As shown in Figure 2, there was no significant variation in the number of true leaves at the seeding stage between the treatments. However, at the budding stage, the number of true leaves on the plants in DT4 was significantly different from those in DT1 and DT5. At the flowering stage, the number of true leaves on the plants in DT3, DT4, and DT6 was significantly different from those in DT1, DT2, and DT5, but there was no significant difference between the DT3 and DT4 plants. At the boll-opening stage, the number of true leaves on the plants in DT1 was significantly lower than on those in DT6, but the number was at a similar level with plants from the other treatments. The largest number of true leaves at any stage of the cotton growth period was 34 in DT6 during the flowering stage. 


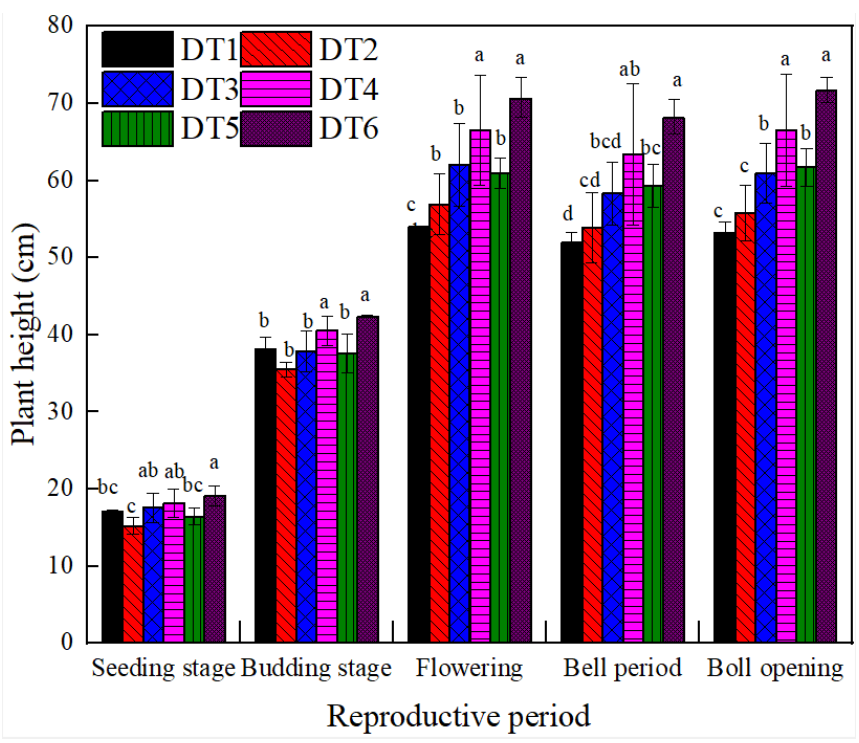

Figure 1. Height of cotton at different growth stages using the different $\mathrm{N}$ fertilizer treatment types (Different lowercase letters at the top of columns indicate significant differences or otherwise insignificant differences).

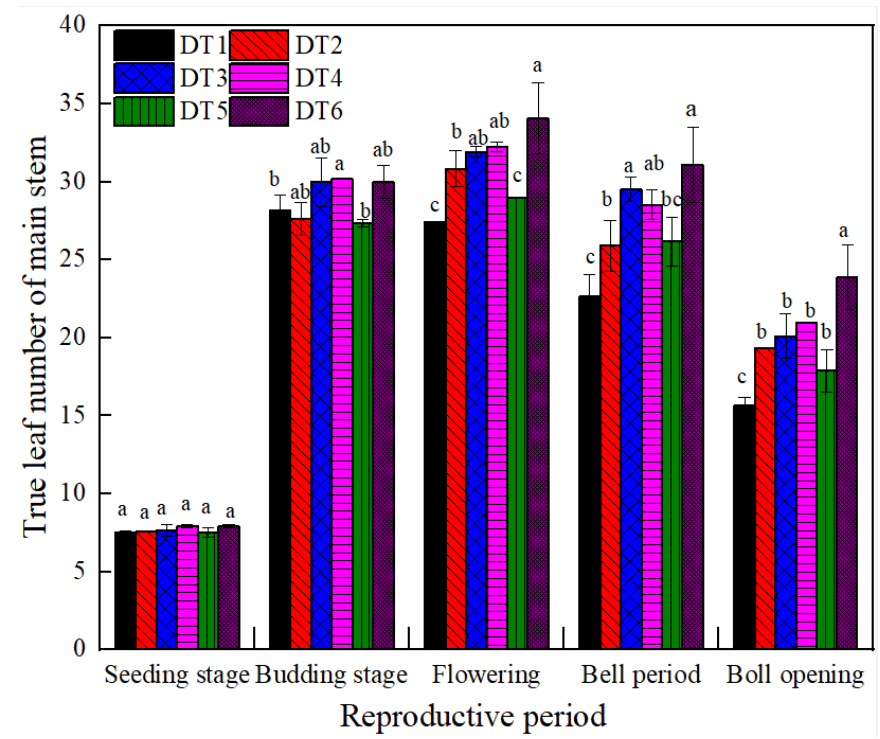

Figure 2. Quantity of true leaves on the main stem of cotton plants using different $\mathrm{N}$ fertilizer treatment types (Different lowercase letters at the top of the columns indicate significant differences or otherwise insignificant differences).

(3) SPAD value of the fourth leaf from the top of the plant.

The fourth leaf from the top of the cotton plant is the main organ of photosynthesis. Chlorophyll is an important pigment that converts light energy into chemical energy, and there is a close relationship between photosynthesis and leaf chlorophyll content. The amount of solar radiation absorbed by leaves is mainly determined by their chlorophyll content, with this chlorophyll content serving as an indicator of the nutritional status of leaves and the degree of senescence. Moreover, a leaf's chlorophyll content is one of the important indicators of the dynamics of a leaf's physiological activity. As shown in Figure 3, at the cotton seedling stage, the SPAD values of the fourth leaf from the top of plants in DT2, DT3, DT5, and DT6 differed significantly from those in DT1 and DT4. In the other four growth stages, the SPAD values of the fourth leaf from the top in plants from the 
five treatments DT2-DT6 were the same, but their values differed significantly from those in DT1.

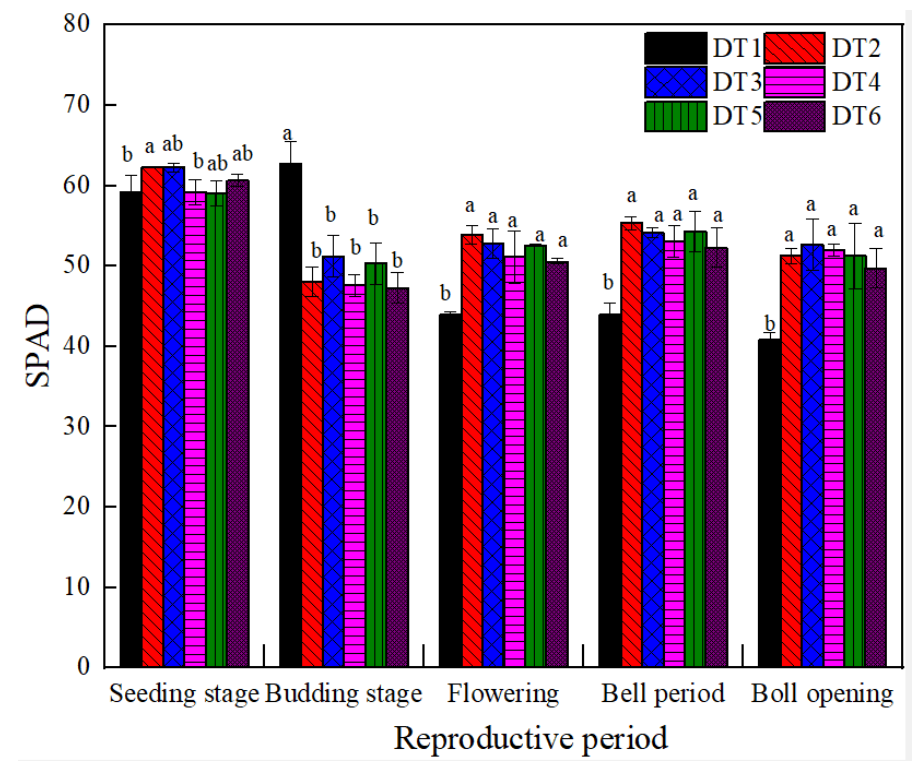

Figure 3. SPAD value of the fourth leaf from the top of the plant using different $\mathrm{N}$ fertilizer treatments (Different lowercase letters at the top of the columns indicate significant differences or otherwise insignificant differences).

(4) Growth curve.

The reproductive organ biomass determines the yield of a cotton plant. Many factors influence a plant's biomass and the parts of the plant from which the biomass is obtained, which then affects the cotton yield. As shown in Figure $4 \mathrm{a}$, the increase in root biomass in plants in DT2 and DT4 slowed down in the boll-forming stage. The increase in root biomass exhibited in plants in DT2 and DT4 prior to the boll-forming stage was also seen in DT6 plants; however, the increase in root biomass during the boll-forming stage was significantly higher in DT6 plants than in DT2 and DT4. This difference is attributed to the fact that $\mathrm{N}$ conservation measures play a major role in supplying $\mathrm{N}$ for root biomass accumulation during the later stages of cotton growth, as is the case with the DT6 plants in this study. Moreover, the traditional fertilization treatment used in DT2 led to low root biomass throughout the cotton plant growth period, but significantly higher leaf biomass compared with the other treatments. The root biomass dynamics were basically the same in the DT5 and DT3 plants, with rapid root growth during the seeding and budding stages, slow root growth from the flowering stage to the boll-forming stage, and rapid root growth again during the boll-forming stage. In contrast, root growth was slow during the seedling, budding, and flowering stages of the DT1 plants, but it increased during the boll-forming and boll-opening stages, leading to the maximum root biomass recorded. This discrepancy was attributed to the fact that DT1 was a non-fertilization treatment, and the supply of necessary nutrients for cotton growth mainly depends on the background soil fertility. The background soil fertility was sufficient for supporting cotton vegetative growth in the early stages, but the demand for nutrients increased during the reproductive growth stages, making it necessary for the cotton plants to continuously transport nutrients from the root system to sustain their reproductive growth, thereby promoting root growth, which is a phenomenon known as cotton resistance to stress. As shown in Figure $4 \mathrm{~b}$, there was the same stem biomass across the treatments during the seedling and flowering stages, but the stem biomass exhibited the same trend in plants in DT2, DT3, and DT6 at the budding and flowering stages, namely a trend of rapid growth. Stem growth slowed down after the bollforming stage, especially after the boll-forming stage of the DT2 plants, when stem growth slowed significantly. This was because the residual soil $\mathrm{N}$ content using the traditional 
treatment was low during the later stages of cotton growth due to the absence of any $\mathrm{N}$ conservation measures, despite the high application rate of a $\mathrm{N}$ fertilizer. A sustained and rapid stem growth was observed in the DT4, DT5, and DT1 plants after the boll-forming stage. DT5 plants had the highest stem biomass of all treatments at the boll-opening stage, and this value was much higher than that of DT6 plants. These findings suggest that the joint application of cotton straws, the nitrification inhibitor, and the urease inhibitor reduced the supply rate of $\mathrm{N}$ but increased the relative content of soil carbon, which was favorable for stem growth. As shown in Figure 4c, the leaf biomass in each treatment increased from the seedling stage, reaching a maximum during the boll-forming stage (except for DT3 plants) and then decreased towards the boll-opening stage. In particular, the leaf biomass at the flowering and boll-forming stages was increased $(p<0.05)$ in DT2 plants than in other treatments, indicating that treatments with higher application rates of a $\mathrm{N}$ fertilizer are more favorable for cotton leaf growth. However, the leaf biomass was significantly lower in DT1 plants than in other treatments at all stages. The leaf biomass in DT3 plants began to decrease after the boll-forming stage, because the nitrification inhibitor reduced the supply of $\mathrm{NO}_{3}{ }^{-}$, thereby inhibiting leaf growth. Leaf biomass showed the same trend in DT4, DT5, and DT6 plants. As shown in Figure 4d, the boll biomass in each treatment showed an increasing trend from the budding stage to the boll-opening stage. At the boll-opening stage, the boll biomass was significantly higher in DT6, DT4, and DT5 plants than in other treatments, while it was lowest in DT1.
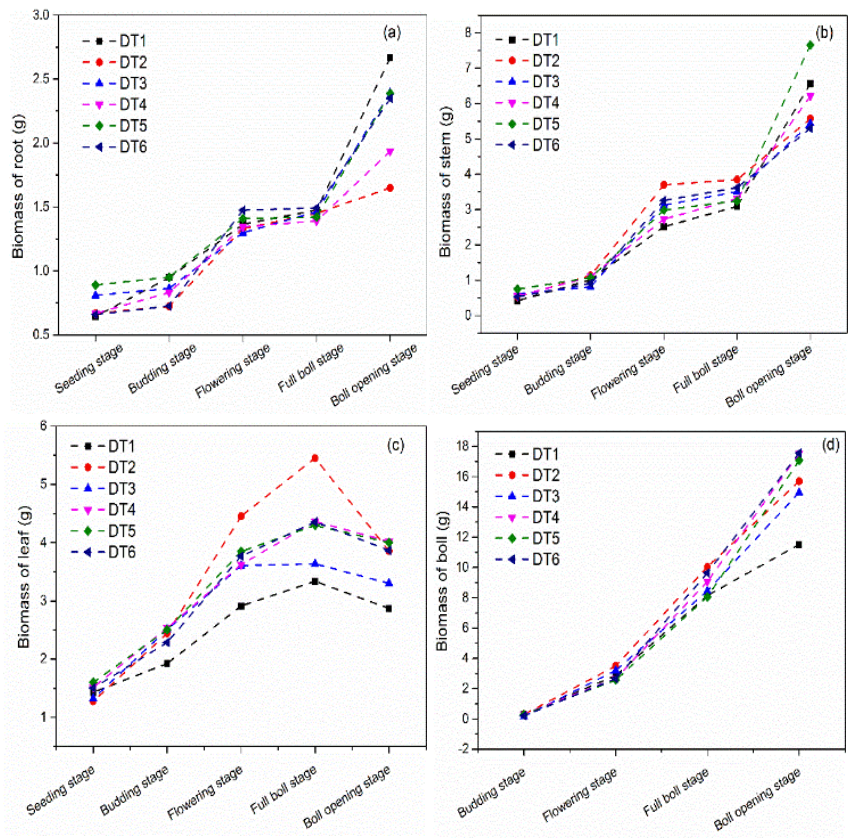

Figure 4. Growth curve of cotton: (a) roots, (b) stems, (c) leaves, and (d) bolls.

\subsection{Cotton Yield}

Table 5 shows that the planting densities of the plants in each treatment type were similar. Improvements in boll number [29] and boll weight [30] are important factors behind a high cotton yield. The numbers of bolls in plants of DT2, DT3, DT4, DT5, and DT6 were significantly different from those in DT1. The highest 100-boll weight was observed in the plants of DT4 and DT2, and there was the same content between the two. The cotton yield in each treatment group decreased in the following order DT4 $>$ DT2 > DT6 $>$ DT3 $>$ DT5 > DT1; DT4 plants had the highest cotton yield, which was higher by $3.32 \%$ than that of plants in DT2, while the cotton yields of plants in DT1, DT3, DT5, and DT6 were lower by $24 \%, 6.36 \%, 8.11 \%$, and $0.13 \%$, respectively, than the DT2 plants. There were no significant differences among the cotton yields of the DT2, DT4, and DT6 plants. 
Table 5. Cotton yields under different nitrogen application levels.

\begin{tabular}{cccccc}
\hline Treatment & $\begin{array}{c}\text { Planting } \\
\text { Density hm }\end{array}$ & $\begin{array}{c}\text { Boll Number } \\
\text { for Each Plant }\end{array}$ & $\begin{array}{c}\text { Weight for } \\
\text { 100 Bolls (g) }\end{array}$ & $\begin{array}{c}\text { Cotton Yield } \\
\text { (kg ha }^{-1} \text { ) }\end{array}$ & $\begin{array}{c}\text { Production } \\
\text { Reduction } \\
\text { over DT2 (\%) }\end{array}$ \\
\hline DT1 & $162,680 \mathrm{a}$ & $2.94 \mathrm{~b}$ & $560.00 \mathrm{c}$ & $2847.57 \mathrm{c}$ & -24.28 \\
DT2 & $156,074 \mathrm{a}$ & $3.92 \mathrm{a}$ & $615.78 \mathrm{ab}$ & $3760.19 \mathrm{a}$ & - \\
DT3 & $161,079 \mathrm{a}$ & $3.51 \mathrm{ab}$ & $606.43 \mathrm{~b}$ & $3521.90 \mathrm{~b}$ & -6.36 \\
DT4 & $152,490 \mathrm{a}$ & $4.02 \mathrm{a}$ & $642.95 \mathrm{a}$ & $3885.77 \mathrm{a}$ & 3.32 \\
DT5 & $152,048 \mathrm{a}$ & $3.63 \mathrm{a}$ & $608.86 \mathrm{~b}$ & $3455.19 \mathrm{~b}$ & -8.11 \\
DT6 & $158,505 \mathrm{a}$ & $3.97 \mathrm{a}$ & $606.46 \mathrm{~b}$ & $3755.99 \mathrm{a}$ & -0.13 \\
\hline
\end{tabular}

\subsection{Nitrogen Use Efficiency at Different Stages}

With sandy loam soil, it is essential to increase $\mathrm{N}$ use efficiency to increase the crop yield. $\mathrm{N}$ use efficiency is generally defined as the ratio of $\mathrm{N}$ absorbed by crop plants during the whole growth period to the total amount of $\mathrm{N}$ fertilizer applied. Cotton has a long growth period that includes a long interval between the application of a basal fertilizer to the first top-dressing application, and $\mathrm{N}$ use efficiency varies dramatically between the different stages. We proposed a concept of phase nitrogen use efficiency (PNUE), which is defined as the proportion of cumulative $\mathrm{N}$ uptake during the period from the application of $\mathrm{N}$ to the end of a given stage in relation to the total amount of $\mathrm{N}$ applied.

As shown in Figure 5, the combined application of NBPT, straw, and DCD in DT6 and the individual applications of DCD, NBPT, and straw in DT3, DT4, and DT5, respectively, resulted in higher PNUE values than seen with DT2. The PNUE up to the end of the seedling and budding stages was higher in DT4 and DT5 than in DT2 and DT6. The PNUE up until the end of the flowering stage was lower in DT2 than in the other treatments, while DT6 had the highest PNUE up until the end of the boll-forming and boll-opening stages. Table 6 indicates that the NUE for each treatment decreased in the following order DT6 $(48.0 \%)>$ DT4 $(43.7 \%)>$ DT3 $(43.1 \%)>$ DT5 $(40.1 \%)>$ DT2 $(26.3 \%)$.

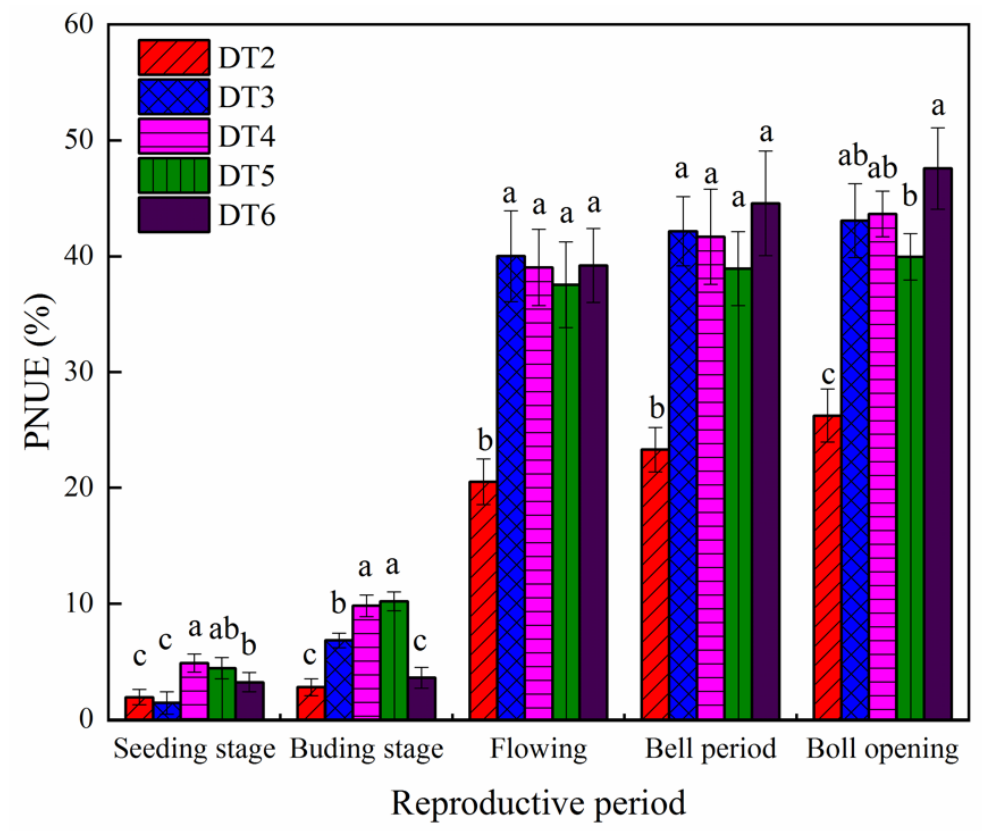

Figure 5. Cumulative nitrogen use efficiency (PNUE) using different nitrogen fertilizer treatments (Different lowercase letters at the top of the columns indicate significant differences or otherwise insignificant differences). 
Table 6. Changes in nitrogen use efficiency (NUE) using different nitrogen fertilizer treatments.

\begin{tabular}{ccc}
\hline Treatment & NUE (\%) & Changes in NUE (\%) \\
\hline DT2 & 26.3 & 0 \\
DT3 & 43.1 & +63.9 \\
DT4 & 43.7 & +66.3 \\
DT5 & 40.1 & +51.8 \\
DT6 & 48.0 & +81.0 \\
\hline
\end{tabular}

\subsection{Nitrogen Uptake by Cotton for the Whole Growth Period}

Net nitrogen accumulation was calculated by multiplying the nitrogen content in dry matter and the dry weight at each growth stage. The amount of $\mathrm{N}$ accumulated during the budding stage in the various treatments decreased in the following order DT4 > DT5 $>$ DT6 > DT2 > DT3 > DT1, and it was significantly higher in DT4 and DT5 than in the other treatments (Table 7). The decreasing order of $\mathrm{N}$ accumulated during the flowering stage in the different treatment groups was DT2 > DT3 > DT4 > DT5 > DT6 > DT1, with significantly higher amounts of N accumulated in DT2 compared with the other treatments. The decreasing order of $\mathrm{N}$ accumulated during the boll-forming stage was DT2 > DT6 $>$ DT3 $>$ DT4 > DT5 > DT1, with significantly higher amounts of N accumulated in DT2 and DT6 compared with the other treatments. The decreasing order of the amount of N accumulated during the boll-opening stage was DT6 > DT3 > DT4 > DT5 > DT2 > DT1, with significantly higher amounts of N accumulated in the DT6, DT3, and DT4 treatments compared with the others. $\mathrm{N}$ accumulation peaked during the flowering stage, regardless of the treatment. From the flowering stage to the boll-forming stage, the decreasing order in the amount of $\mathrm{N}$ accumulated in the treatments was DT2 $>$ DT6 $>$ DT3 $>$ DT4 $>$ DT5 $>$ DT1 The net amount of $\mathrm{N}$ accumulated was the highest in DT2. During the boll-opening stage, the amount of $\mathrm{N}$ accumulated was lower in DT2 than in the other treatments. With respect to the ratio of $\mathrm{N}$ accumulated at a given stage to the total $\mathrm{N}$ accumulated within the entire growth period, the ratio in DT2 reached a maximum before the flowering stage but decreased during the boll-forming stage. The same trend was also observed for DT3. In contrast, the amount of N accumulated in DT4, DT5, and DT6 increased significantly during the boll-forming stage. The amount of N accumulated in DT1 was high before the flowering stage, but it decreased during the boll-opening stage. This can be attributed to the fact that the background soil fertility met the needs of the cotton plants in the early growth stages, but the soil's $\mathrm{N}$ levels failed to meet the reproductive growth needs of the plants as they continued to grow in the later stages.

\subsection{Residual Characteristics and Changes in $\mathrm{NO}_{3}{ }^{-}$and $\mathrm{NH}_{4}{ }^{+}$within Tillage Soil under Different Treatments}

Irrigated fertilization was applied eight times during the study. Dynamic measurements of soil $\mathrm{NO}_{3}{ }^{-}$and $\mathrm{NH}_{4}{ }^{+}$in the $0-20 \mathrm{~cm}$ tillage layer were obtained each day after the first two rounds of sixteen days of irrigated fertilization and every week after the last six rounds. The contents of $\mathrm{NO}_{3}{ }^{-}$and $\mathrm{NH}_{4}{ }^{+}$in the $0-20 \mathrm{~cm}$ tillage layer were dynamically determined using a continuous flow analyzer. As shown in Figure $6 \mathrm{a}$, the soil $\mathrm{NO}_{3}{ }^{-}$ content increased to a certain extent in all treatments except for DT1 (no N applied), and the increase was particularly obvious in the soil of DT2, DT5, and DT6. The soil $\mathrm{NO}_{3}{ }^{-}$content first increased and then decreased over time with all of the fertilizer treatments, except for DT2, where the soil $\mathrm{NO}_{3}{ }^{-}$content peaked twice during the period from 21 June to 5 July. As shown in Figure 6b, the maxima for soil $\mathrm{NH}_{4}{ }^{+}$content were above $6 \mathrm{mg} \mathrm{kg}^{-1}$ in all treatments except for DT1. The soil $\mathrm{NH}_{4}{ }^{+}$content was low within the first four days after $\mathrm{N}$ was applied; it then showed a decreasing trend over time but peaked again during the last 4-7 post-application days (when it rapidly increased and then decreased), which indicates that the onset of rapid urea decomposition was delayed. There were multiple peak values in the $\mathrm{NH}_{4}{ }^{+}$content of the soil of DT3, which indicates that the nitrification inhibitor plays an important role in retaining soil ammonium $\mathrm{N}$. In the DT4 soil, the $\mathrm{NH}_{4}{ }^{+}$content first 
increased and then gradually decreased following irrigated fertilization. In the DT5 soil, the $\mathrm{NH}_{4}{ }^{+}$content peaked twice during the period from 21 June to $5 \mathrm{July}$, which indicates that the post-application release of fertilizer $\mathrm{N}$ into the soil occurred more than once and that it also occurred in the later stages. Compared with the other treatments, the soil $\mathrm{NH}_{4}{ }^{+}$ content showed a greater number of peak values in DT6, where the soil $\mathrm{NH}_{4}{ }^{+}$content remained close to the peak values for a longer duration than with the other treatments, and the inter-peak intervals were shorter. This result indicates that the joint application of a nitrification inhibitor, urease inhibitor, and returned straws provides a better result than the application of any of the three individually.

Table 7. The stages of $\mathrm{N}$ accumulation in cotton under different levels of $\mathrm{N}$ fertilizer treatments.

\begin{tabular}{|c|c|c|c|c|}
\hline Growth Period & Treatment & $\begin{array}{l}\text { N Accumulation } \\
\left(\mathrm{kg} \mathrm{ha}^{-1}\right)\end{array}$ & $\begin{array}{c}\text { Net } N \text { Accumulation } \\
\text { at Each Stage } \\
\left(\mathrm{kg} \mathrm{ha}^{-1}\right)\end{array}$ & $\begin{array}{c}\text { Net N Accumulation } \\
\text { at Each Stage/Total N (\%) }\end{array}$ \\
\hline \multirow[t]{6}{*}{ Budding stage } & DT1 & $11.6 \mathrm{~d} \pm 0.4$ & - & 38.00 \\
\hline & DT2 & $12.9 \mathrm{~b} \pm 0.4$ & - & 70.02 \\
\hline & DT3 & $12.3 c \pm 0.4$ & - & 54.52 \\
\hline & DT4 & $13.8 \mathrm{a} \pm 0.4$ & - & 45.01 \\
\hline & DT5 & $13.4 \mathrm{a} \pm 0.5$ & - & 46.81 \\
\hline & DT6 & $13.1 b \pm 0.6$ & - & 45.65 \\
\hline \multirow[t]{6}{*}{ Flowering } & DT1 & $24.1 \mathrm{c} \pm 0.7$ & 12.4 & 7.64 \\
\hline & DT2 & $41.5 \mathrm{a} \pm 0.7$ & 34.9 & 16.22 \\
\hline & DT3 & $39.8 b \pm 0.5$ & 30.1 & 3.06 \\
\hline & DT4 & $38.3 b \pm 0.6$ & 24.5 & 3.64 \\
\hline & DT5 & $37.1 b \pm 0.5$ & 23.7 & 2.02 \\
\hline & DT6 & $40.0 \mathrm{~b} \pm 0.3$ & 26.9 & 6.77 \\
\hline \multirow[t]{6}{*}{ Boll period } & DT1 & $26.6 c \pm 0.3$ & 2.5 & 18.79 \\
\hline & DT2 & $47.9 \mathrm{a} \pm 0.3$ & 8.0 & 4.01 \\
\hline & DT3 & $44.2 \mathrm{~b} \pm 0.4$ & 1.6 & 20.06 \\
\hline & DT4 & $40.3 b \pm 0.3$ & 1.9 & 25.94 \\
\hline & DT5 & $38.1 \mathrm{c} \pm 0.4$ & 1.0 & 24.64 \\
\hline & DT6 & $47.0 \mathrm{a} \pm 0.7$ & 7.0 & 25.44 \\
\hline \multirow[t]{6}{*}{ Boll opening } & DT1 & $32.8 c \pm 0.4$ & 6.1 & - \\
\hline & DT2 & $49.9 b \pm 0.5$ & 2.0 & - \\
\hline & DT3 & $55.2 \mathrm{a} \pm 0.6$ & 11.0 & - \\
\hline & DT4 & $54.4 \mathrm{a} \pm 0.7$ & 14.1 & - \\
\hline & DT5 & $50.6 b \pm 0.6$ & 12.4 & - \\
\hline & DT6 & $59.0 \mathrm{a} \pm 0.8$ & 15.0 & - \\
\hline
\end{tabular}



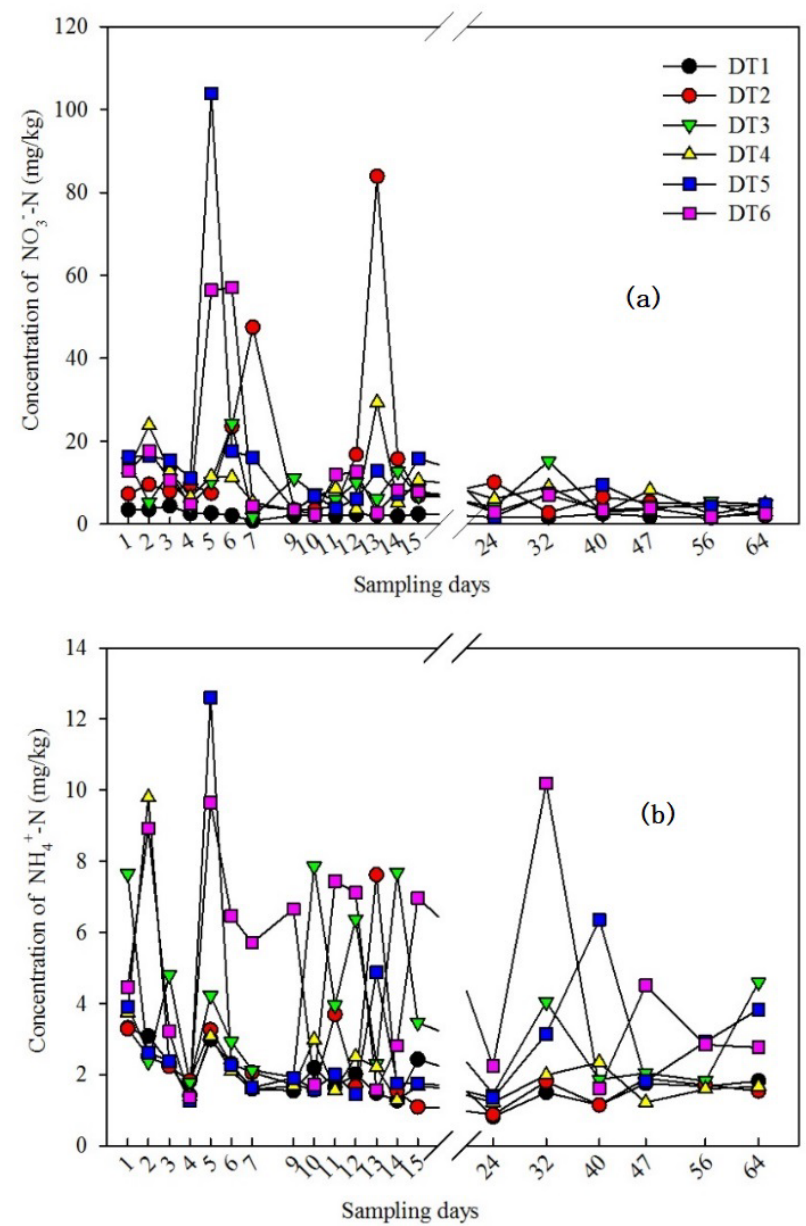

Figure 6. Concentrations of $\mathrm{NO}_{3}{ }^{-}$(a) and $\mathrm{NH}_{4}{ }^{+}$(b) in the soil at a depth of $0-20 \mathrm{~cm}$.

\section{Discussion}

Nitrogen is the most vital mineral nutrient for crop growth, and its deficiency can result in changes in the growth, yield, and physiological status of cotton plants. Our study demonstrated that for urea applied at $60 \%$ of the conventional rate, $\mathrm{N}$ use efficiency was improved in the presence of DCD, NBPT, and cotton straw together, or in the presence of only one of these three. In contrast, N use efficiency was the lowest in DT2. In this respect, the application of urea alone in DT2 promoted soil nitrification/denitrification, which in turn promoted soil $\mathrm{N}_{2} \mathrm{O}$ emissions and $\mathrm{N}$ loss. However, $\mathrm{N}$ use efficiency in DT5, where urea was applied only with returned straws, was lower than that of the other fertilizer treatments. Compared with DT6, the decomposition of the cotton straws in DT5 resulted in soil $\mathrm{N}$ consumption, as the straws competed with the cotton plants for $\mathrm{N}$ adsorption. When applied to the soil, the cotton straws underwent decomposition, which consumed $\mathrm{O}_{2}$ in the soil and intensified denitrification, thus leading to the consumption of soil $\mathrm{N}$. During the boll-forming and boll-opening stages, straw-induced denitrification became less obvious as the straws continued to decompose, and the top-dressing applied in these later stages ensured a continuous supply of $\mathrm{N}$. As a result, the leaf and boll biomass increased again during these stages. In DT6, the addition of cotton straws together with DCD and NBPT prolonged the effective duration of the $\mathrm{N}$ fertilizer in the soil and increased the $\mathrm{C} / \mathrm{N}$ ratio. A higher ratio of active organic carbon to $\mathrm{NO}_{3}{ }^{-}$is favorable for the reduction of nitrate $\mathrm{N}$ to ammonium $\mathrm{N}$ and thus for $\mathrm{N}$ fixation [31]. A common practice adopted by local farmers for cotton planting in southern Xinjiang is to crush straws and directly apply them to the fields.

Compared with DT3 and DT4, DT6 provided N conservation measures that involved the application of DCD, NBPT, and straws, and the straws served to increase the ratio of 
active $\mathrm{C}$ to $\mathrm{N}$ [32-34], thereby improving the $\mathrm{N}$ fixation efficiency. In DT4, the root biomass was relatively low after the boll-forming stage because of the low $\mathrm{N}$ use efficiency (due to the unfavorable $\mathrm{N}$ uptake conditions).

Cotton yields were lower in DT1, DT5, and DT3 than in DT2, but there were no significant differences between DT4, DT2, and DT6. Kawakami et al. [9] found that joint application of urea at $75 \%$ of the conventional rate with DCD and NBPT reduced the $\mathrm{N}$ uptake of cotton, which adversely affected cotton growth and led to lower yields. This observation is consistent with our results which show that the inclusion of DCD in DT3 resulted in a lower cotton yield. However, Di and Cameron [35] reported that the application of DCD has been reported as being beneficial in enhancing $\mathrm{N}$ fertilizer efficiency and crop yields. It may be that DCD can reduce $\mathrm{N}$ loss in various ways [20,36].

The yield reduction in this study can be attributed to the following: DCD increases stomatal conductance [37] and has a positive impact on photosynthesis and the yield under good precipitation conditions [38]. However, it has a negative impact when precipitation is insufficient or when there is severe water loss [39]. The present test field was located in the extremely arid area of the Tarim Basin where precipitation is scarce and evaporation is strong, which also aggravates ammonia volatilization loss.

The benefits of simultaneous fertilization with NBPT and urea have been well documented [40]. The application of NBPT on silt loam and clay loam can reduce $\mathrm{NH}_{3}$ volatilization losses by $89 \%$ and $47 \%$, respectively [41]. NBPT also has a positive effect on the chlorophyll content, growth, and yield of cotton plants [9]. In this study, there was the same content between the cotton yields of DT4 and DT2, but the application rate of urea in DT4 was $60 \%$ that of DT2, which suggests that NBPT played an important role in increasing the cotton yield. This accords with the previous finding of Earnest and Varco [42]. This effect could be attributed to the inhibition of urea hydrolysis by urease inhibitors, which delays the changeover of amide $\mathrm{N}$ to $\mathrm{NH}_{4}{ }^{+}-\mathrm{N}$ and reduces the soil $\mathrm{NH}_{4}{ }^{+}$ content, thereby decreasing the volatilization of $\mathrm{NH}_{3}$. The observed performance of NBPT confirmed that ammonia volatilization loss is a key factor influencing the $\mathrm{N}$ use efficiency of urea. In contrast, the use of straws in DT6 increased soil C/N ratios and thus facilitated $\mathrm{N}$ fixation, which prolonged the effective duration of $\mathrm{N}$ fertilizer in the soil. DCD can inhibit the conversion of $\mathrm{NH}_{4}{ }^{+}-\mathrm{N}$ to $\mathrm{NO}_{3}{ }^{-}$and reduce the leaching of $\mathrm{NO}_{3}{ }^{-}$, and NBPT can reduce the volatilization loss caused by the conversion of $\mathrm{NH}_{4}{ }^{+}$to $\mathrm{NH}_{3}$, especially in sandy loam in extremely arid areas. The test soil in this study was alkaline, which facilitated the changeover of $\mathrm{NH}_{4}{ }^{+}$to $\mathrm{NH}_{3}$ and also the volatilization loss of $\mathrm{N}$. Consequently, the DT6 treatment provided the highest yield. The planting environment and planting time of crops are very important factors in the accumulation of biomass [43], as well as in respect of nitrogen accumulation and the $\mathrm{C} / \mathrm{N}$ ratio of cotton.

The $\mathrm{NO}_{3}{ }^{-}$and $\mathrm{NH}_{4}{ }^{+}$contents of the $0-20 \mathrm{~cm}$ soil layer in each test plot showed a general, gradual, decreasing trend with time following the top-dressing application, and dropped to low levels after two weeks. The soil $\mathrm{NO}_{3}{ }^{-}$content was lower in DT3, where DCD was used, than in DT2, DT4, and DT6, which indicates that DCD has a good inhibitory effect on the changeover of $\mathrm{N}$ to $\mathrm{NO}_{3}{ }^{-}$in soil, thereby indirectly reducing the leaching of nitrate $\mathrm{N}$. The retention of soil $\mathrm{NH}_{4}{ }^{+}$in the different treatments decreased in the order of DT6 > DT3 > DT5 > DT4. Therefore, the combined addition of DCD and NBPT with cotton straws outperformed fertilizer treatments without cotton straws in terms of $\mathrm{NH}_{4}{ }^{+}$retention in the soil. However, soil $\mathrm{N}$ is not only found in the form of nitrate $\mathrm{N}$ and ammonium $\mathrm{N}$, it also exists in organic $\mathrm{N}$ and mineralized $\mathrm{N}$. Moreover, the conditions affecting the conversion between different $\mathrm{N}$ forms are complex. This study only compared the dynamics of the $\mathrm{NO}_{3}{ }^{-}$and $\mathrm{NH}_{4}{ }^{+}$contents within the $0-20 \mathrm{~cm}$ tillage layer of the cotton fields after an irrigated top-dressing was applied of the different fertilization treatments. Therefore, the $\mathrm{NO}_{3}{ }^{-}$and $\mathrm{NH}_{4}{ }^{+}$contents and other $\mathrm{N}$ forms (such as organic $\mathrm{N}$ ) in the deep soil layers have yet to be investigated. 


\section{Conclusions}

This study focused on the extremely arid Tarim Basin in Xinjiang, China to explore the differences in the $\mathrm{NO}_{3}{ }^{-}-\mathrm{N}$ and $\mathrm{NH}_{4}{ }^{+}-\mathrm{N}$ contents of tillage soil and in the growth status and yield of cotton under different $\mathrm{N}$ conservation measures, after reducing the $\mathrm{N}$ fertilization rate to $60 \%$ of the traditional rate adopted by local farmers. The main points arising from the results of the study are as follows.

Adding NBPT (DT4) and DCD, NBPT, and straw (DT6) can both reduce the amount of nitrogen fertilizer needed by $40 \%$ and ensure cotton yield. Especially, using a urea, DCD, NBPT, and straw treatment (DT6) increases plant height, the SPAD value of the fourth leaf from the top, and the number of true leaves on the main stem of cotton plants. However, treatment DT3, in which DCD was added at $10 \%$ of the nitrogen (N) application amount, failed to simultaneously achieve $\mathrm{N}$ conservation and an increased yield. The application of straws without DCD and NBPT (DT5) was favorable for the vegetative growth of cotton in the early stages; however, it was unfavorable for reproductive growth during the later stages. Thus, long-term $\mathrm{N}$ accumulation was not achieved.

Under the test conditions in this study, the joint application of $60 \%$ urea with straws, DCD, and NBPT in treatment DT6 achieved the highest N use efficiency of $48 \%$. This result was higher than the $\mathrm{N}$ use efficiency in any other treatment in which a single $\mathrm{N}$ conservation measure was adopted. Optimizing the proportion of straws, DCD, and NBPT utilized will be the focus of our next study.

In the time interval between two adjacent rounds of drip fertilization, the residual content of nitrate $\mathrm{N}$ in the tillage layer increased gradually with time, while that of ammonium N showed no obvious trend. During the entire drip irrigation and fertilization process, the residual content of nitrate $\mathrm{N}$ and ammonium $\mathrm{N}$ in the tillage layer showed a gradually decreasing trend regardless of $\mathrm{N}$ conservation measures. Thus, the application of $\mathrm{N}$ fertilizers at a reduced rate in conjunction with $\mathrm{N}$ conservation measures may reduce the residual content of $\mathrm{N}$ in soil and decrease the risk of non-point source pollution of $\mathrm{N}$ fertilizers, while maintaining the cotton yield.

Author Contributions: Conceptualization, J.Z. (Jianbin Zhou) and J.Z. (Jinhu Zhi); methodology, J.Z. (Jinhu Zhi); software, M.X.; validation, X.B., M.X. and Z.C.; formal analysis, T.Q.; investigation, J.Z. (Jinhu Zhi); resources, J.Z. (Jinhu Zhi); data curation, T.Q.; writing-original draft preparation, J.Z. (Jinhu Zhi); writing—review and editing, J.Z. (Jinhu Zhi); visualization, T.Q.; supervision, J.Z. (Jianbin Zhou) project administration, J.Z. (Jinhu Zhi); funding acquisition, J.Z. (Jinhu Zhi). All authors have read and agreed to the published version of the manuscript.

Funding: This research was funded by National Natural Science Foundation of China (32060259), including Research and Demonstration of SPAC Water Migration Simulation and Effect Evaluation for Cotton Field under Filmless Cultivation Mode in Southern Xinjiang.

Conflicts of Interest: The authors declare no conflict of interest.

\section{References}

1. Yang, G.; Tang, H.; Nie, Y.; Zhang, X. Responses of cotton growth, yield, and biomass to nitrogen split application ratio. Eur. J. Agron. 2011, 35, 164-170. [CrossRef]

2. Cao, L. Changing Port Governance Model: Port Spatial Structure and Trade Efficiency. J. Coast. Res. 2020, 95, 963-968. [CrossRef]

3. Duan, Y.; Liu, Y.; Chen, Z.; Liu, D.; Yu, E.; Zhang, X.; Fu, H.; Fu, J.; Zhang, J.; Du, H. Amorphous molybdenum sulfide nanocatalysts simultaneously realizing efficient upgrading of residue and synergistic synthesis of 2D MoS2 nanosheets/carbon hierarchical structures. Green Chem. 2020, 22, 44-53. [CrossRef]

4. Wang, Z.; Huang, Z.; Brosnahan, J.T.; Zhang, S.; Guo, Y.; Guo, Y.; Wang, L.; Wang, Y.; Zhan, W. Ru/CeO 2 Catalyst with Optimized $\mathrm{CeO}_{2}$ Support Morphology and Surface Facets for Propane Combustion. Environ. Sci. Technol. 2019, 53, 5349-5358. [CrossRef]

5. Yang, G.-Z.; Luo, X.-J.; Nie, Y.-C.; Zhang, X.-L. Effects of Plant Density on Yield and Canopy Micro Environment in Hybrid Cotton. J. Integr. Agric. 2014, 13, 2154-2163. [CrossRef]

6. Huber, D.M.; Warren, H.L.; Nelson, D.W.; Tsai, C.Y. Nitrification Inhibitors: New Tools for Food Production. Bioscience 1977, 27, 523-529. [CrossRef]

7. Davidson, E.A.; David, M.B.; Galloway, J.N.; Goodale, C.L.; Haeuber, R.; Harrison, J.A.; Howarth, R.W.; Jaynes, D.B.; Lowrance, R.R.; Nolan, B.T.; et al. Excess nitrogen in the US environment: Trends, risks, and solutions. Issues Ecol. 2012, 15, 1-16. 
8. de Vries, W.; Kros, J.; Kroeze, C.; Seitzinger, S.P. Assessing planetary and regional nitrogen boundaries related to food security and adverse environmental impacts. Curr. Opin. Environ. Sustain. 2013, 5, 392-402. [CrossRef]

9. Kawakami, E.M.; Oosterhuis, D.M.; Snider, J.L.; Mozaffari, M. Physiological and yield responses of field-grown cotton to application of urea with the urease inhibitor NBPT and the nitrification inhibitor DCD. Eur. J. Agron. 2012, 43, 147-154. [CrossRef]

10. Amberger, A. Research on dicyandiamide as a nitrification inhibitor and future outlook. Commun. Soil Sci. Plant Anal. 1989, 20, 1933-1955. [CrossRef]

11. Zaman, M.; Zaman, S.; Adhinarayanan, C.; Nguyen, M.; Nawaz, S.; Dawar, K. Effects of urease and nitrification inhibitors on the efficient use of urea for pastoral systems. Soil Sci. Plant Nutr. 2013, 59, 649-659. [CrossRef]

12. Khan, M.J.; Malik, A.; Zaman, M.; Khan, Q. Nitrogen use efficiency and yield of maize crop as affected by agrotain coated urea in arid calcareous soils. Soil Environ. 2014, 33, 1-6.

13. Rawluk, C.D.L.; Grant, C.A.; Racz, G.J. Ammonia volatilization from soils fertilized with urea and varying rates of urease inhibitor NBPT. Can. J. Soil Sci. 2001, 81, 239-246. [CrossRef]

14. Watson, C.J.; Miller, H.; Poland, P.; Kilpatrick, D.J.; Allen, M.D.; Garrett, M.K.; Christianson, C.B. Soil properties and the ability of the urease inhibitor $\mathrm{N}-(\mathrm{n}$-butyl) thiophosphoric triamide (nBTPT) to reduce ammonia volatilization from surface-applied urea. Soil Biol. Biochem. 1994, 26, 1165-1171. [CrossRef]

15. Creason, G.L.; Schmitt, M.R.; Douglass, E.A.; Hendrickson, L.L. Urease inhibitory activity associated with N-(n-butyl) thiophosphoric triamide is due to formation of its oxon analog. Soil Biol. Biochem. 1990, 22, 209-211. [CrossRef]

16. Kolodziej, A.F. The Chemistry of Nickel-Containing Enzymes. Prog. Inorg. Chem. 1994, 41, 493-597.

17. Hartmann, T.E.; Guzman-Bustamante, I.; Ruser, R.; Müller, T. Turnover of Urea in a Soil from the North China Plain as Affected by the Urease Inhibitor NBPT and Wheat Straw. Agronomy 2020, 10, 857. [CrossRef]

18. Khan, M.A.; Shah, Z.; Rab, A.; Arif, M.; Shah, T. Effect of urease and nitrification inhibitors on wheat yield. Sarhad J. Agric. 2013, 29, 371-378.

19. Halvorson, A.D.; Snyder, C.S.; Blaylock, A.D.; Del Grosso, S.J. Enhanced-efficiency nitrogen fertilisers: Potential role in nitrous oxide emission mitigation. Agron. J. 2014, 106, 715-722. [CrossRef]

20. Ruser, R.; Schulz, R. The effect of nitrification inhibitors on the nitrous oxide (N2O) release from agricultural soils-A review. J. Plant Nutr. Soil Sci. 2015, 178, 171-188. [CrossRef]

21. Vogeler, I.; Blard, A.; Bolan, N. Modelling DCD effect on nitrate leaching under controlled conditions. Soil Res. 2007, 45, 310-317. [CrossRef]

22. Qiao, C.; Liu, L.; Hu, S.; Compoton, J.E.; Greaver, T.L.; Li, Q. How inhibiting nitrification affects nitrogen cycle and reduces environmental impacts of anthropogenic nitrogen input. Glob. Chang. Biol. 2015, 21, 1249-1257. [CrossRef]

23. Qiaogang, Y.; Jianzhen, Y.; Junwei, M. Effects of nitrification inhibitor DMPP application in agricultural ecosystems and their influencing factors: A review. J. Agro-Environ. Sci. 2014, 33, 1057-1066.

24. Fatokun, K.; Beckett, R.; Varghese, B.; Sershen; Pammenter, N. Germination indices of orthodox seeds as influenced by controlled deterioration and cathodic water seed invigoration. J. Environ. Biol. 2020, 41, 1105-1111. [CrossRef]

25. Romano, N.; Fischer, H.; Egnew, N. Color and sugar preferences of adult black soldier fly (hermetia illucens) (dipetera:stratiomyidae) for feeding and oviposition. J. Environ. Biol. 2020, 41, 1132-1137. [CrossRef]

26. Singh, R.; Kumar, G. Ionizing radiation mediated effect on morphological, biochemical and microsporogenesis behavior of Artemisia annua L. J. Environ. Biol. 2020, 41, 1046-1053. [CrossRef]

27. Xia, M.; Chen, Z.; Gao, J.; Liu, Z.; Li, H.; Zhou, J. Summer fallow increases loss of residual nitrogen fertiliser in dryland of the Loess Plateau: A 15N-labeled method. Environ. Sci. Pollut. Res. 2018, 25, 34155-34163. [CrossRef]

28. Muneer, A. Effect of Urease Inhibitor on Reducing Nitrogen Losses and Improving Nitrogen Use Efficiency. Ph.D. Thesis, Northwest A\&F University, Xianyang, China, 2018.

29. Bondada, B.R.; Oosterhuis, D.M. Canopy photosynthesis, specific leaf weight, and yield components of cotton under varying nitrogen supply. J. Plant Nutr. 2001, 24, 469-477. [CrossRef]

30. Mauney, J.R.; Stewart, J.M. Cotton Physiology; Cotton Foundation: Memphis, Ten, USA, 1986.

31. Silver, W.L.; Herman, D.C.; Firestone, M.K. Dissimilatory nitrate reduction to ammonium in upland tropical forest soils. Ecology 2001, 82, 2410-2416. [CrossRef]

32. Wang, W.; Lai, D.; Wang, C.; Pan, T.; Zeng, C. Effects of rice straw incorporation on active soil organic carbon pools in a subtropical paddy field. Soil Tillage Res. 2015, 152, 8-16. [CrossRef]

33. Song, X.; Li, L.; Zheng, J.; Pan, G.; Zhang, X.; Zheng, J.; Hussain, Q.; Han, X.; Yu, X. Sequestration of maize crop straw C in different soils: Role of oxyhydrates in chemical binding and stabilization as recalcitrance. Chemosphere 2012, 87, 649-654. [CrossRef]

34. Song, X.; Li, Y.; Yue, X.; Hussain, Q.; Zhang, J.; Liu, Q.; Jin, S.; Cui, D. Effect of cotton straw-derived materials on native soil organic carbon. Sci. Total Environ. 2019, 663, 38-44. [CrossRef] [PubMed]

35. Di, H.; Cameron, K. The use of a nitrification inhibitor, dicyandiamide (DCD), to decrease nitrate leaching and nitrous oxide emissions in a simulated grazed and irrigated grassland. Soil Use Manag. 2002, 18, 395-403. [CrossRef]

36. Akiyama, H.; Yan, X.; Yagi, K. Evaluation of effectiveness of enhanced-efficiency fertilisers as mitigation options for $\mathrm{N} 2 \mathrm{O}$ and $\mathrm{NO}$ emissions from agricultural soils: Meta-analysis. Glob. Change Biol. 2010, 16, 1837-1846. [CrossRef] 
37. Reeves, D.; Touchton, J.T.; Rickerl, D.H. Effect of nitrogen source and dicyandiamide on growth and water relations of cotton. Soil Sci. Soc. Am. J. 1988, 52, 281-285. [CrossRef]

38. Frye, W.; Graetz, D.; Locascio, S.; Reeves, D.; Touchton, J. Dicyandiamide as a nitrification inhibitor in crop production in the Southeastern USA. Commun. Soil Sci. Plant Anal. 1989, 20, 1969-1999. [CrossRef]

39. Gordon, W.; Rikerl, D.H.; Touchton, J.T. Effects of nitrogen, dicyandiamide, and tillage on cotton nitrogen concentration and yield. Agron. J. 1990, 82, 597-600. [CrossRef]

40. Mozaffari, M.; Slaton, N.A.; Long, J.; Kelley, J.; Chlapecka, R.; Wimberley, R. Effect of urea and urea treated with Agrotain ${ }^{\mathrm{TM}}$ on corn grain yield in Arkansas. In Soil Fertility Studies; Arkansas Agricultural Experiment Station: Fayetteville, AR, USA, 2007; p. 38.

41. Gioacchini, P.; Nastri, A.; Marzadori, C.; Giovannini, C.; Antisari, L.V.; Gessa, C. Influence of urease and nitrification inhibitors on N losses from soils fertilized with urea. Biol. Fertil. Soils 2002, 36, 129-135. [CrossRef]

42. Earnest, R.E.; Varco, J.J. Fertiliser nitrogen source and placement, and Agrotain ${ }^{\circledR}$ effects on no-till cotton N-use efficiency. In Proceedings of the Beltwide Cotton Conferences, San Antonio, TX, USA, 4-6 January 2022.

43. Gómez, L.D.; Amalfitano, C.; Andolfi, A.; Simister, R.; Somma, S.; Ercolano, M.R.; Borrelli, C.; McQueen-Mason, S.J.; Frusciante, L.; Cuciniello, A.; et al. Valorising faba bean residual biomass: Effect of farming system and planting time on the potential for biofuel production. Biomass Bioenergy 2017, 107, 227-232. [CrossRef] 